\title{
The effectiveness of growth cycles on improving fruit quality for grafted watermelon combinations
}

\author{
Ozlem ALAN ${ }^{1}$, Fatih SEN ${ }^{2}$, Eftal DUZYAMAN ${ }^{2}$
}

\begin{abstract}
Two growth cycles per year, i.e., for early growing season (EGS) and late growing season (LGS) production, both of which are widely preferred in temperate climates, have been investigated for their effects on fruit quality attributes such as appearance; firmness; the content of total soluble solids, sugars, and total phenol; and antioxidant activity. Two watermelon [Citrullus lanatus (Thunb.) Matsum and Nakai] cultivars (cv. 'Anthem $\mathrm{F}_{1}$ ' and $\mathrm{cv}$. 'Crimstar $\mathrm{F}_{1}$ ') were used as scion. Two C. maxima $\times$ C. moschata hybrids (cv. 'Shintoza F90' cv. 'Obez') and one Lagenaria siceraria rootstock cv. 'Macis' were used as rootstock. Self-rooted and self-grafted plants were used as controls. EGS resulted in a reduction of fruit shape index, rind thickness, juice $\mathrm{pH}$, hue values, and glucose content as compared to LGS for both the cultivars. On the other hand, total soluble solids of cv. 'Crimstar', fructose of cv. 'Anthem', and the antioxidant activity of cv. 'Anthem' increased. The total phenol content was unaffected by the scion/rootstock combinations or growth seasons for both the cultivars. Most of the fruit quality attributes increased when a specific rootstock/scion combination and growth season was used and these combinations may change in relation to cultivar. It is important to evaluate and select suitable scion/rootstocks for each growth condition created by ecology and growth cycle to guarantee high fruit quality.
\end{abstract}

Keywords: Citrullus lanatus; rootstock-scion combination; taste compounds; antioxidant activity; total phenol.

Practical Application: Several conflicting reports exist on modification in the fruit quality of grafted watermelon and whether the grafting effects are advantageous or deleterious. However, there is no data available on how growth cycles affect quality traits and health-related compounds of grafted watermelons. In addition, several rootstock or scion varieties are developed under environments that differ from those in target production areas. Assessing the consistency of combination performance across locations and/or time is thus important for farmers. Such studies are therefore needed to assist in the selection of a rootstock/scion combination in order to maintain consumer satisfaction and improve our understanding of the relative contributions of rootstock/scion combination and environment to variability in quality traits. It can be concluded that it is important to evaluate and select suitable scion/rootstocks for each growth condition created by ecology and growth cycle to guarantee high fruit quality.

\section{Introduction}

Research on vegetable grafting first began in Japan in the late 1920 s on watermelons with respect to scope with soil pathogens and has been much studied since then. In the last few decades, however, vegetable grafting has also been performed to enhance tolerance to abiotic stresses, increase efficiency of water and nutrient uptake, and improves fruit yield and quality (Bletsos \& Passam, 2010; King et al., 2010). Inevitably, grafting of vegetables increasingly popularized, with increase in the proportion and species diversity and elevation in the routine technique used for continuous cropping systems in several parts of the world (Lee et al., 2010).

Once grafted, almost all parts of a watermelon plant are affected. Besides disease resistance and tolerance to low/high soil temperatures, watermelon rootstocks, especially those of C. maxima $\times$ C. moschata hybrids can enhance plant vigor, growth, and yield since they are much more vigorous than the bottle gourd rootstock (Alan et al., 2007; King et al., 2010); however, reports on fruit quality such as rind thickness, color, fruit firmness, total soluble solids, and sugar are rather conflicting being increasing, decreasing or remaining unaffected (Miguel et al., 2004; Davis et al., 2008a; Rouphael et al., 2010; Fallik \& Ilic, 2014; Kyriacou et al., 2017).

In order to find meaningful explanations for the fluctuations in fruit quality parameters when watermelons are grafted, for instance, considered several fruit quality traits to depend on both rootstock and scion by indicating rootstock/scion incompatibility as the reason for decreased scion fruit quality. Grafting incompatibility usually occurs at the early stages of growth of a plant when the vascular connections are still forming. However, it can also arise as late as the fruiting stage 
when the demand for water and nutrients increases by the plant (Aloni et al., 2010; Martinez-Ballesta et al., 2010). The same authors also discussed that rootstock/scion incompatibility may be caused by unfavorable environmental conditions. Hence, it is unrealistic to expect a perfect match between the environmental conditions in the breeding location of watermelon scions and rootstocks and their ultimate production area. Edelstein et al. (2014), focused attentions to both scion-rootstock interactions and growing conditions when the fruit quality traits are questioned. Other authors have emphasized that not only the fruit quality but also health-related biochemical compounds such as phenols and antioxidants are affected when an unsuitable, rootstock-scion combinations are selected (Candır et al., 2013; Schwarz et al., 2013).

Farmers in several watermelon-producing countries, especially in the temperate regions such as Spain, Italy, Greece, and Turkey prefer to grow watermelons in one of the two main production cycles, that is, the early season or the late season (Benincasa et al., 2014). Achieving early and late watermelon production represents the key factor for farmers to increase their net income (Ibarra et al., 2001). The early growing season (EGS) starts under low plastic tunnels in April when the soil and air temperatures are not suitable and continues as an open field production when the temperatures rise. The late growing season (LGS), on the other hand, starts directly in the open fields by the end June to the beginning of July and continues until autumn, when the soil and air temperatures become unsuitable. Plants may be easily exposed to sub-optimal air and soil temperatures during the EGS, while the LGS can create a heat-stress at the beginning of the production cycle in the mid-summer. Regarding growing season Alan et al. (2017) reported that the LGS creates a better environment for plant growth traits (main stem length, number of lateral vine, shoots dry weight etc.).

As in several other watermelon-producing countries, the use of grafted seedlings is quite widespread in Turkey, with the interspecific hybrid Cucurbita maxima $\times$ C. moschata as the prevailing rootstock, followed by Lagenaria siceraria. Recommendations of consultants, advisors of seed and seedling companies, and experienced growers can be effective in deciding for a commercial rootstock trademark. The main selection criterion in deciding for a rootstock appears to be disease-resistance and vigorous plant growth, while rootstock/scion combination and graft affinity is rather neglected (Rouphael et al., 2010).

Despite that several studies exist on changes in fruit quality in grafted watermelons grown in different environments, there is no data available on how growing cycles affect quality traits of grafted watermelons. The purpose of this study was to evaluate different rootstock/scion combinations for fruit quality traits and biochemical compounds under early and late seasons. The objectives of this study were i) to collect information about the changes in fruit quality traits and health-compounds for two watermelon-growing cycles in a temperate region, ii) to elucidate the importance of selecting a suitable scion/rootstock combination, and iii) to discuss possible reasons for fluctuations of fruit quality parameters among different rootstock/scion combinations across both the growing seasons.

\section{Materials and methods}

\subsection{Material}

The EGS and LGS field trials were set up in summer 2012 in the experimental fields of Ödemiş Vocational School at Ege University, Izmir, Turkey (latitude $38^{\circ} 12^{\prime} \mathrm{N}$, longitude $27^{\circ} 52^{\prime} \mathrm{E}$, altitude $111 \mathrm{~m}$ ). Two watermelon [Citrillus lanatus (Thunb.) Matsum \& Nakai] cultivars namely cv. 'Anthem F' ' (Poltar Seed Company, Turkey) and cv. 'Crimstar F,' (Sakata Seed Company, USA) were selected as scion material. These cultivars are widely grown commercial production of watermelon in Turkey. Three commercial rootstocks were also selected, two of which were hybrids of C. maxima $\times$ C. moschata, namely cv. 'Shintoza F90' (SemillasFito, Spain) and cv. 'Obez' (Nickerson-Zwaan Seed Company, The Netherlands), and one being Lagenaria siceraria, cv. 'Macis' (Nunhems Seed Company, The Netherlands) that were compared with self-rooted and self-grafted ones. Cv. 'Shintoza F90', cv. 'Obez' and cv. 'Macis' are among the most popular rootstocks commercially available for watermelon grafting worldwide (Davis et al., 2008b; Dadashpour, 2012). The grafting combinations used in this study are given in Table 1.

Seedlings of scions and rootstocks were grown in climate-controlled greenhouses, where cultural practices were performed as described by Doolan et al. (1999). Scions and rootstocks were grafted in all combinations using the tongue approach grafting technique described by Lee et al. (2010) and Mohamed et al. (2014).

The Early Growing Season (EGS): Grafted and self-rooted seedlings were planted in the soil on the $4^{\text {th }}$ of April (target transplanting in the early spring) under low plastic tunnels, which were removed on the $3^{\text {rd }}$ of May when the air temperature became suitable for watermelon $\left(20-25^{\circ} \mathrm{C}\right)$. Three subsequent harvests were performed between 19 June and 8 July for EGS.

The Late Growing Season (LGS): Grafted and self-rooted seedlings were planted in the soil on the $21^{\text {st }}$ of June (target transplanting in early summer) directly in open field, and three subsequent harvests were performed between 07 August and 11 September for LGS.

The soil of the experimental site was sandy loam composed of $1.3 \%$ organic matter and $0.08 \%$ total salt, at a $\mathrm{pH}$ of 7.7 . All plants (for EGS and LGS) were spaced at $1.18 \mathrm{~m} \times 2.80 \mathrm{~m}$ within and between rows, respectively, giving a density of 3050 plants/ha. The experimental design was factorial experiment in a completely randomized block design with 3 replicates, with 10 plants in each replicate. Plants were fertilized to an equivalent of $150 \mathrm{~kg} \mathrm{~N} / \mathrm{ha}$, $120 \mathrm{~kg} \mathrm{P} \mathrm{O}_{5} / \mathrm{ha}, 200 \mathrm{~kg} \mathrm{~K} \mathrm{O} / \mathrm{ha}$, and $150 \mathrm{~kg} \mathrm{Ca}\left(\mathrm{NO}_{3}\right)_{2} / \mathrm{ha}$ based on the soil test results. The entire phosphorous content was

Table 1. Grafting combinations used in the experiments.

\begin{tabular}{cc}
\hline Cv. 'Anthem' & Cv. 'Crimstar' \\
\hline Anthem / Shintoza & Crimstar / Shintoza \\
Anthem / Obez & Crimstar / Obez \\
Anthem / Macis & Crimstar / Macis \\
Anthem / Anthem (self-grafted) & Crimstar / Crimstar (self-grafted) \\
Anthem & Crimstar \\
(self-rooted or non-grafted) & (self-rooted or non-grafted) \\
\hline
\end{tabular}


applied prior to planting, while the nitrogen, potassium, and half of the calcium contents were divided into 5 equal portions and applied through an irrigation system. The other half of the calcium content was sprayed directly onto the plants. Weeding and spraying against pests were done as needed.

Ripe fruits with completely dried stipule and tendrils on the same node were harvested (Karaca et al., 2012), and 5 fruits from each replicate were randomly selected from among the marketable fully ripe fruits for analysis. After determining the fruit shape index (fruit length/fruit diameter) and rind thickness $(\mathrm{mm})$ the fruits were kept at $-22{ }^{\circ} \mathrm{C}$ until further quality assessments were performed.

\subsection{Quality attributes}

Fruits were prepared for analyses by defrosting, cutting into two equal halves from the central section, and removing the seeds. The total soluble solids (TSS) content of the fruits were measured in the juice derived from the central endocarp by using a digital refractometer (PR-1; Atago, Tokyo, Japan).The same juice was also subjected to the measurement of $\mathrm{pH}$ using a Mettler Toledo type $\mathrm{pH}$ meter (MP220, Switzerland).

Measurements of flesh firmness of fruits were performed using an Effegi penetrometer (FT 011; Effegi, Japan) which involved measuring the force (in kilograms) required for an 11-mm probe to penetrate the cut surface to a depth of $2 \mathrm{~cm}$ at 8 locations in the mesocarp tissue. The data were then calculated as the means of the measurements from each fruit sample and expressed in Newton $(\mathrm{N})$.

The fruit flesh color were measured at the equatorial level at 8 locations in the mesocarp tissue using a colorimeter (CR-400; Minolta Co., Osaka, Japan), which provided the values $\mathrm{L}^{*}, \mathrm{a}^{*}$ and $\mathrm{b}^{*}$. Color values represented a light-dark spectrum from 0 (black) to 100 (white), a green-red spectrum from -60 (green) to +60 (red), and a blue-yellow spectrum from -60 (blue) to +60 (yellow), respectively. These color values were then used to calculate Chroma $\left(\mathrm{C}^{\star}=\left[\mathrm{a}^{\star 2}+\mathrm{b}^{\star 2}\right]^{1 / 2}\right)$, which indicates the intensity or color saturation, and hue angle $\left(\mathrm{h}^{\circ}=\tan ^{-1}\left[\mathrm{~b}^{*} / \mathrm{a}^{*}\right]\right)$, which is expressed in degrees: $0^{\circ}$ (red-purple), $90^{\circ}$ (yellow), $180^{\circ}$ (bluish-green), and $270^{\circ}$ (blue) (McGuire, 1992).

Sugar analysis was performed in homogenized frozen samples. For this process, the samples were filtered through a 0.20 - $\mu \mathrm{m}$ filter paper, diluted with deionized distilled water, and injected directly into the HPLC equipment (Thermo Dionex UltiMate 3000 Series, ThermoScientific, ABD). The HPLC analysis of sugars was performed on equipment consisting of refractive index detector (RefractoMax 520, ERC Inc., Japan) and Hypersil GOLD Amino column ( $150 \mathrm{~mm} \times 4.6 \mathrm{~mm}$, ThermoScientific, USA) at a flow rate of $0.1 \mathrm{ml} / \mathrm{min}$ (Chinnici et al., 2005). Acetonitrile:distilled water (80:20) mixture was used as a mobile phase. The results of fructose, glucose and sucrose are related to $\mathrm{g} / 100 \mathrm{~g}$ fruit fresh weight.

\subsection{Total phenolic content and antioxidant activity}

Fruit extracts were prepared by using the methods of Thaipong et al. (2006), with slight modifications for the analyses of total phenolic content and antioxidant activity. Total phenol content was determined using the Folin-Ciocalteu method (based on the methods of Swain \& Hillis, 1959), with an incubation time of $120 \mathrm{~min}$ for color development. The absorbance was measured at $725 \mathrm{~nm}$ using a spectrophotometer (Carry 100 Bio; Varian, Mulgrave, Australia), and the results were expressed as mg gallic acid equivalent (GAE)/100 $\mathrm{g}$ fresh weight (FW) using a gallic acid $(0-0.1 \mathrm{mg} / \mathrm{mL})$ standard curve.

The ferric-reducing ability of plasma (FRAP) assay was performed as previously described by Benzie \& Strain (1996). In this method, reductants (antioxidants) in the sample reduce a $\mathrm{Fe}$ (III)/tripyridyltriazine complex to its blue ferrous form, increasing absorbance at $593 \mathrm{~nm}$. The final results were expressed in $\mu \mathrm{mol}$ Trolox equivalents (TE)/g fresh weight (FW) using a Trolox $(25-500 \mu \mathrm{mol})$ standard curve.

\subsection{Statistical analysis}

All collected data analyzed as a factorial experiment in a completely randomized block design by the analyses of variance (ANOVA) using SPSS ${ }^{\circ}$ version 19 statistical software on an $\mathrm{IBM}^{\circ}$ computer. Each treatment was replicated 3 times, with 5 fruit in each replication. Significant differences among the groups were determined by Duncan's multiple range test at $p \leq 0.05$.

\section{Results and discussion}

The fruit shape index, rind thickness, juice $\mathrm{pH}$, firmness, color characteristics $\left(\mathrm{C}^{*}\right.$ and $\mathrm{h}^{\circ}$ values, ) and TSS of experimental parameters are presented in Table 2. The fruit shape index was found to be significant for both the cultivars $(p \leq 0.01)$ in both the growing seasons $(p \leq 0.01)$. Self-rooted cv. 'Anthem' and cv. 'Crimstar' had the lowest fruit shape index as compared to the grafted plants for both the growing seasons. It was also noted that 'Anthem'/'Macis' (1.24) for EGS and 'Anthem'/'Shintoza' (1.30) and 'Anthem'/'Obez' (1.28) for LGS had higher fruit index than others. For cv. 'Crimstar,' 'Crimstar'/'Shintoza' (1.09), and 'Crimstar'/'Obez' (1.09) for the EGS, 'Crimstar'/'Shintoza' (1.17) for LGS had the highest fruit index. According to the mean values, the LGS increased the fruit shape index of cv. 'Anthem' and cv. 'Crimstar' by an average of $10.6 \%$ and $4.7 \%$, respectively in comparison to the EGS. Fruit size is the most prominent change following grafting of watermelon onto rootstocks. Contrarily to the fruit size, the fruit shape index defined by the ratio of equatorial and longitudinal lengths was unaffected or minimal by grafting combinations on watermelon grown under low tunnel and in open field conditions (Davis \& Perkins-Veazie, 2005; Alan et al., 2007; Rouphael et al., 2010; Kyriacou et al., 2017). Our findings of an increase in the fruit shape index agree with a later report of Turhan et al. (2012).

Rind thickness was significant only in scion-rootstock combinations performed with cv. 'Anthem' in the LGS $(p \leq 0.01)$. The thickest rind was obtained from self-rooted 'Anthem' with $19.3 \mathrm{~mm}$, while grafted plants had similar values and lower rind thickness for the LGS. Self-rooted 'Anthem' also showed the highest rind thickness $(13.3 \mathrm{~mm})$ for EGS, but the difference was not statistically significant. Contrarily to the cv. 'Anthem', rootstock-scion combinations showed no effect on the rind thickness of cv. 'Crimstar' neither during the EGS 
nor the LGS. Although the difference was not statistically significant, self-rooted 'Crimstar' showed the lowest rind thickness. According to the mean values, the LGS increased the thickness of cv. 'Anthem' and cv. 'Crimstar' by an average of $14.6 \%$ and $22.0 \%$, respectively, as compared to EGS. Contrarily to the our results, the previous results showed that fruit rinds of 'CrimsonTide' grafted on Lagenaria were significantly (21\%) thicker (Yetişir et al., 2003), \% thicker when 'Crimson Sweet' was grafted on Lagenaria (Alexopoulos et al., 2007), and 17\% thicker in 'Ingrid' mini-watermelon grafted on Cucurbita rootstock (Proietti et al., 2008) as compared to their non-grafted counterparts.
Non-significant differences in the juice $\mathrm{pH}$ of cv. 'Anthem' were detected in the LGS, but the juice $\mathrm{pH}$ was significantly affected by the rootstock-scion combinations in the EGS $(p \leq 0.01)$. 'Anthem'/'Macis' had the highest juice pH (5.33), while 'Anthem'/'Obez' (5.15) had the lowest in the EGS. Significant differences in the juice $\mathrm{pH}$ of $\mathrm{cv}$. 'Crimstar' were found for only LGS ( $p \leq 0.05)$. Self-rooted 'Crimstar' fruits had higher juice $\mathrm{pH}$ than grafted 'Crimstar' plants, independent of rootstocks. According to the mean values, the juice $\mathrm{pH}$ of LGS was slightly greater (by 5.7\%) for cv. 'Anthem' and (by 3.7\%) for cv. 'Crimstar', as compared to EGS. The above results are in agreement for only cv.'Crimstar' with those obtained by Soteriou et al. (2014)

Table 2. Changes in the fruit quality parameters of cv's 'Anthem' and 'Crimstar', depending on the different rootstock-scion combinations in both the growing seasons.

\begin{tabular}{|c|c|c|c|c|c|c|c|c|}
\hline \multicolumn{9}{|c|}{ cv. 'Anthem' } \\
\hline Factor & & $\begin{array}{l}\text { Fruit shape } \\
\text { index }\end{array}$ & $\begin{array}{l}\text { Rind } \\
\text { thickness } \\
(\mathrm{mm})\end{array}$ & $\begin{array}{l}\text { Juice } \\
\mathrm{pH}\end{array}$ & $\begin{array}{c}\text { Firmness } \\
(\mathrm{N})\end{array}$ & $C^{*}$ & $\mathrm{~h}^{\circ}$ & $\begin{array}{c}\text { Total soluble } \\
\text { solid } \\
(\%)\end{array}$ \\
\hline \multirow[t]{6}{*}{ EGS } & Shintoza & $1.00 \mathrm{bc}$ & 12.3 & $5.18 \mathrm{~cd}$ & 15.1 & $28.7 \mathrm{a}$ & 27.3 & 9.2 \\
\hline & Obez & $1.15 \mathrm{ab}$ & 12.0 & $5.15 \mathrm{~d}$ & 14.7 & $29.0 \mathrm{a}$ & 25.9 & 9.5 \\
\hline & Macis & $1.24 \mathrm{a}$ & 12.3 & $5.33 \mathrm{a}$ & 13.2 & $27.6 \mathrm{ab}$ & 26.6 & 10.1 \\
\hline & Self-grafted & $1.17 \mathrm{ab}$ & 11.8 & $5.25 \mathrm{bc}$ & 13.3 & $25.7 \mathrm{~b}$ & 25.9 & 9.0 \\
\hline & Self-rooted & $1.09 \mathrm{c}$ & 13.3 & $5.26 \mathrm{~b}$ & 11.9 & $26.2 \mathrm{~b}$ & 26.4 & 9.4 \\
\hline & Significance & $* *$ & ns & $* *$ & ns & * & ns & ns \\
\hline \multirow[t]{6}{*}{ LGS } & Shintoza & $1.30 \mathrm{a}$ & $13.8 \mathrm{~b}$ & 5.48 & 14.0 & $26.6 \mathrm{~b}$ & $28.9 \mathrm{a}$ & 10.0 \\
\hline & Obez & $1.28 \mathrm{a}$ & $14.2 \mathrm{~b}$ & 5.46 & 14.6 & $31.3 \mathrm{a}$ & $27.2 \mathrm{~b}$ & 10.8 \\
\hline & Macis & $1.26 \mathrm{ab}$ & $11.4 \mathrm{~b}$ & 5.64 & 13.4 & $26.1 \mathrm{~b}$ & $29.4 \mathrm{a}$ & 9.9 \\
\hline & Self-grafted & $1.24 \mathrm{ab}$ & $12.0 \mathrm{~b}$ & 5.56 & 13.6 & $26.3 \mathrm{~b}$ & $29.7 \mathrm{a}$ & 9.7 \\
\hline & Self-rooted & $1.17 \mathrm{~b}$ & $19.3 \mathrm{a}$ & 5.58 & 12.2 & $26.6 \mathrm{~b}$ & $29.8 \mathrm{a}$ & 10.1 \\
\hline & Significance & $* *$ & $* *$ & ns & ns & * & * & ns \\
\hline \multirow{3}{*}{$\begin{array}{l}\text { Growing } \\
\text { Season }\end{array}$} & EGS & $1.13 \mathrm{~b}$ & $12.3 \mathrm{~b}$ & $5.24 \mathrm{~b}$ & 13.6 & 27.4 & $26.4 \mathrm{~b}$ & $9.5 \mathrm{~b}$ \\
\hline & LGS & $1.25 \mathrm{a}$ & $14.1 \mathrm{a}$ & $5.54 \mathrm{a}$ & 13.6 & 27.4 & $29.0 \mathrm{a}$ & $10.1 \mathrm{a}$ \\
\hline & Significance & * & $* *$ & $* *$ & ns & ns & $* *$ & $* *$ \\
\hline Interaction & Significance & $* *$ & $* *$ & ns & ns & ns & * & ns \\
\hline \multicolumn{9}{|c|}{ cv. 'Crimstar' } \\
\hline Factor & & $\begin{array}{c}\text { Fruit shape } \\
\text { index }\end{array}$ & $\begin{array}{l}\text { Rind } \\
\text { thickness } \\
(\mathrm{mm})\end{array}$ & $\begin{array}{l}\text { Juice } \\
\mathrm{pH}\end{array}$ & $\begin{array}{l}\text { Firmness } \\
(\mathrm{N})\end{array}$ & $C^{*}$ & $\mathrm{~h}^{\circ}$ & $\begin{array}{c}\text { Total soluble } \\
\text { solid } \\
(\%)\end{array}$ \\
\hline \multirow[t]{6}{*}{ EGS } & Shintoza & $1.09 \mathrm{a}$ & 11.6 & 5.48 & $13.8 \mathrm{bc}$ & 29.9 & 28.2 & 10.7 \\
\hline & Obez & $1.09 \mathrm{a}$ & 11.6 & 5.44 & $15.7 \mathrm{a}$ & 29.9 & 29.0 & 10.0 \\
\hline & Macis & $1.06 \mathrm{ab}$ & 11.3 & 5.39 & $15.0 \mathrm{ab}$ & 28.6 & 29.0 & 10.5 \\
\hline & Self-grafted & $1.07 \mathrm{ab}$ & 10.9 & 5.34 & $14.4 \mathrm{ab}$ & 26.5 & 27.8 & 9.8 \\
\hline & Self-rooted & $1.03 \mathrm{~b}$ & 9.2 & 5.40 & $12.6 \mathrm{c}$ & 28.5 & 27.6 & 10.2 \\
\hline & Significance & $* *$ & ns & ns & * & ns & ns & ns \\
\hline \multirow[t]{6}{*}{ LGS } & Shintoza & $1.17 \mathrm{a}$ & 13.5 & $5.48 \mathrm{~b}$ & $15.7 \mathrm{a}$ & $30.2 \mathrm{a}$ & $29.1 \mathrm{~b}$ & $9.4 \mathrm{~b}$ \\
\hline & Obez & $1.14 \mathrm{ab}$ & 12.8 & $5.56 \mathrm{~b}$ & $14.7 \mathrm{ab}$ & $29.4 \mathrm{a}$ & $28.9 \mathrm{~b}$ & $10.7 \mathrm{a}$ \\
\hline & Macis & $1.12 \mathrm{ab}$ & 14.5 & $5.51 \mathrm{~b}$ & $13.8 \mathrm{bc}$ & $30.5 \mathrm{a}$ & $28.4 \mathrm{~b}$ & $9.3 \mathrm{~b}$ \\
\hline & Self-grafted & $1.12 \mathrm{ab}$ & 14.0 & $5.54 \mathrm{~b}$ & $11.9 \mathrm{~d}$ & $31.3 \mathrm{a}$ & $28.9 \mathrm{~b}$ & $10.3 \mathrm{a}$ \\
\hline & Self-rooted & $1.05 \mathrm{~b}$ & 12.0 & $5.74 \mathrm{a}$ & $12.5 \mathrm{~cd}$ & $26.3 \mathrm{~b}$ & $30.7 \mathrm{a}$ & $8.9 \mathrm{~b}$ \\
\hline & Significance & $* *$ & ns & * & $* *$ & * & * & $* *$ \\
\hline \multirow{3}{*}{$\begin{array}{c}\text { Growing } \\
\text { Season }\end{array}$} & EGS & $1.07 \mathrm{~b}$ & $10.9 \mathrm{~b}$ & $5.4 \mathrm{~b}$ & 14.3 & 28.7 & $28.3 \mathrm{~b}$ & $10.3 \mathrm{a}$ \\
\hline & LGS & $1.12 \mathrm{a}$ & $13.3 \mathrm{a}$ & $5.6 \mathrm{a}$ & 13.7 & 29.6 & $29.2 \mathrm{a}$ & $9.8 \mathrm{~b}$ \\
\hline & Significance & $* *$ & $* *$ & $* *$ & ns & ns & $* *$ & $* *$ \\
\hline Interaction & Significance & * & ns & * & $* *$ & $*$ & $* *$ & $* *$ \\
\hline
\end{tabular}

${ }^{*} \mathrm{p} \leq 0.05 ;{ }^{* *} \mathrm{p} \leq 0.01$. ns: not significant. Mean separation within columns by Duncan's multiple range test. $\mathrm{P} \leq 0.05$. 
who pointed out that grafting has been found to reduce the $\mathrm{pH}$ of the pulp.

Rootstock-scion combinations showed no effect on the firmness of cv. 'Anthem neither in the EGS nor in the LGS. Although the difference was not statistically significant, self-rooted 'Anthem' showed the lowest firmness for both the growing seasons. In contrast to the cv. 'Anthem', significant differences were found in the firmness of cv. 'Crimstar' both during the EGS and LGS ( $p \leq 0.05$ in EGS and $p \leq 0.01$ in LGS). The highest firmness was obtained from 'Crimstar'/'Obez' for the EGS; from 'Crimstar'/'Shintoza' for the LGS. It was also noted that the growing season had no effect on the firmness for both the cultivars. Flesh firmness is one of the typical attributes used to describe fruit texture. In many cases, an improvement has been observed in grafted plants (Davis et al., 2008a, b).

$\mathrm{C}^{\star}$ values of $\mathrm{cv}$. 'Anthem' were affected significantly by the rootstock-scion combinations in both the growing seasons (both $p \leq 0.05$ ). The highest $C^{*}$ values were obtained from 'Anthem'/'Obez' (29.0) and 'Anthem'/'Shintoza' (28.7) in the EGS and from 'Anthem'/'Obez' (31.3) in the LGS. The $\mathrm{C}^{\star}$ values of cv. 'Crimstar' were only affected significantly by the rootstock-scion combinations in the LGS $(p \leq 0.05)$. The lowest $\mathrm{C}^{*}$ value was obtained from self-rooted 'Crimstar' (26.3), while all grafted plants showed the highest $C^{\star}$ values. The $h^{\circ}$ value was found significant for both the cultivars in the LGS (both $p \leq 0.05$ ). The lowest $h^{\circ}$ value was obtained from 'Anthem'/'Obez', while the other grafted and self-rooted 'Anthem' had the highest. The highest $h^{\circ}$ value was obtained from self-rooted 'Crimstar', while the other grafted 'Crimstar' fruits showed the lowest. According to the mean values, the LGS increased the $h^{\circ}$ value of cv. 'Anthem' and cv. 'Crimstar' by an average of $9.8 \%$ and 3.2\%, respectively, as compared to the EGS, while the growing season had no effect on the $\mathrm{C}^{\star}$ value Regarding colour. Karaca et al. (2012) reported that colour parameters of the fruits harvested from the grafted and control plants were found to be similar, except for a limited number of graft combinations.

The rootstock-scion combinations had no effect on the TSS content of $\mathrm{cv}$. 'Anthem neither during the EGS nor during the LGS. Significant differences were noted in the TSS content of cv. 'Crimstar' were found for only the LGS $(p \leq 0.01)$ and rootstock-scion combinations analyzed declined in the following order: 'Crimstar'/'Obez'> self-grafted 'Crimstar' >'Crimstar'/'S hintoza'>'Crimstar'/'Macis'> self-rooted 'Crimstar'. It can also been seen that, LGS increased the TSS content for cv. 'Anthem' by an average of $6.3 \%$, but decreased for cv. 'Crimstar' by an average of $5.1 \%$ as compared to the EGS.

Table 3 presents the sugar content of rootstock-scion combinations for two growing seasons. Fructose $(p \leq 0.05$ in the EGS and $p \leq 0.01$ in the LGS), glucose ( $p \leq 0.05$ in the EGS and $p \leq 0.01$ in the LGS), sucrose, and total sugar (both $p \leq 0.01$ ) were found to be significant for cv. 'Anthem' in both the growing seasons. Self-rooted cv. 'Anthem' plants showed higher fructose and glucose content for the EGS and the LGS. The highest sucrose and total sugar contents were obtained from 'Anthem'/'Macis' for both the EGS and LGS. 'Anthem'/'Shintoza' also increased the sucrose content only for the EGS and self-rooted cv. 'Anthem' plants also increased the total sugar content only for the LGS. On the other hand, changes in the fructose and glucose contents of cv. 'Crimstar' were only significant for the LGS ( $p \leq 0.01$ and $p \leq 0.05$, respectively); sucrose of cv. 'Crimstar' was significant only for the EGS $(p \leq 0.01)$. The highest fructose $(1.92 \mathrm{~g} / 100 \mathrm{~g})$ and glucose $(1.94 \mathrm{~g} / 100 \mathrm{~g})$ content were obtained from self-rooted 'Crimstar' fruits. The higher sucrose content was determined in 'Crimstar'/'Shintoza' (3.94 g/100 g) and 'Crimstar'/'Macis' $(3.68 \mathrm{~g} / 100 \mathrm{~g})$ combinations. Interestingly, high total sugar content was reported for 'Crimstar'/'Shintoza' (7.08 g/100 g) in the EGS ( $p \leq 0.05)$, however self-rooted 'Crimstar' $(7.18 \mathrm{~g} / 100 \mathrm{~g})$ did it better in the case of LGS $(p \leq 0.05)$. According to the mean values, in cv. 'Anthem'; EGS increased the fructose content by $11 \%$, decreased the glucose content by $15 \%$, and had no effect on the sucrose and total sugar content. In cv. 'Crimstar', EGS increased only glucose content by $25.7 \%$ and had no effect on the fructose, sucrose, and total sugar content. Literature relating to the effects of grafting on the total soluble solids and sugar content in watermelon fruits is not consistent. No difference was found in the soluble solid concentrations and soluble sugars (glucose, fructose, and sucrose) in fruits developed from watermelon scions grafted onto a squash interspecific hybrid vs. fruits from non-grafted watermelons (Miguel et al., 2004; Colla et al., 2006; Proietti et al., 2008; Huitrón-Ramírez et al., 2009). Liu et al. (2004) reported that some Cucurbita spp. rootstocks decreased the total soluble solids content of watermelon fruits, but Salam et al. (2002) reported a marked increase in the total soluble solids in grafted watermelons. Yetişir et al. (2003) suggested that the total soluble solids and sugar content were greatly affected by grafting, albeit the results were dependent on the rootstock used. In addition, Davis et al. (2008b) indicated in their review that watermelon maturity is often delayed in grafted fruit and that this difference in maturation probably causes additional contradictory reports in the literature. In our study, although significant differences in the total soluble solid content and total sugars were noted with the growing seasons and individual rootstock-scion combinations, the resulting trend was inconsistent.

The total phenol values were not affected significantly by any of the factors for both the cultivars (Table 3). The total phenol values varied between $13.11 \mathrm{mg}$ GAE/100 g FW (self-grafted in LGS) and $16.88 \mathrm{mg} \mathrm{GAE} / 100 \mathrm{~g} \mathrm{FW}$ ('Macis'/Anthem' in EGS) for cv. 'Anthem'; and between $12.07 \mathrm{mg} \mathrm{GAE} / 100 \mathrm{~g} \mathrm{FW}$ ('Crimstar'/'Obez' in EGS) and $15.38 \mathrm{mg}$ GAE/100 g FW ('Crimstar'/'Obez' in LGS) for cv. 'Crimstar'. Phenolic compounds were found in considerable quantities in several fruits and vegetables and thus formed an integral part of the human diet. The study of these fruits and vegetables attracted great interest because their consumption is associated with reduced risks of cardiovascular disease and certain types of cancer (Hamid et al., 2010). Similarly Chávez-Mendoza et al. (2013) demonstrated that, in pepper plants, grafting had no effect on the total phenol content of the fruit. In contrast, Evrenosoğlu et al. (2010) observed that the watermelon variety 'Crispy' grafted onto commercial hybrid rootstocks 'TZ 148' and 'RS 841' (both C. maxima x C. moschata rootstocks) showed increased phenolic content in comparison to non-grafted plants in two growing periods (April and June). These researchers also noted that the total phenolic content of watermelons grafted onto ' $64-18$ ' rootstock, which is Lagenaria, was similar to that of non-grafted plants. 
Table 3. Changes in sugar contents, total phenol, and antioxidant activity of cv's 'Anthem' and 'Crimstar' depending upon different rootstock-scion combinations in both the growing seasons.

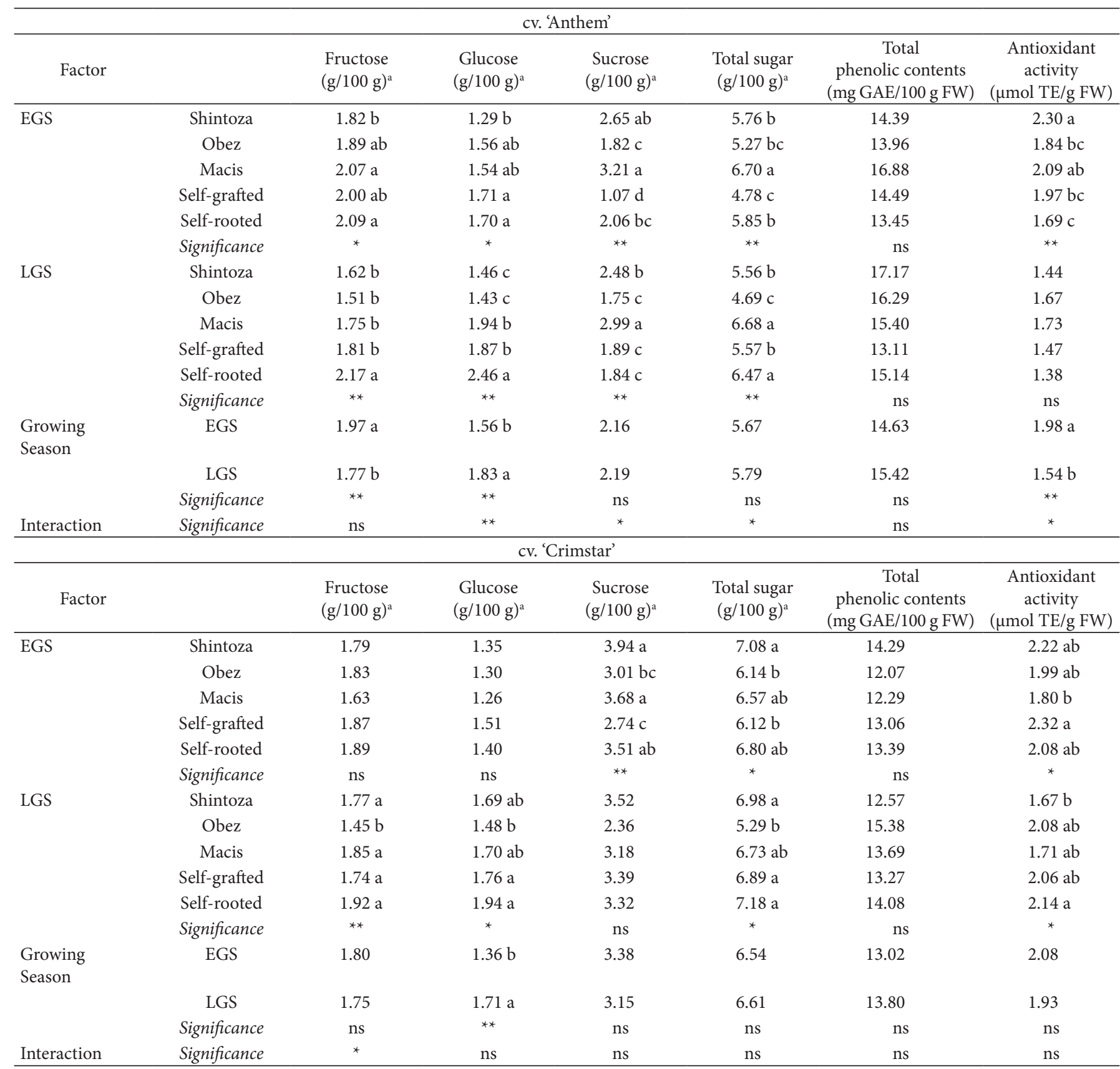

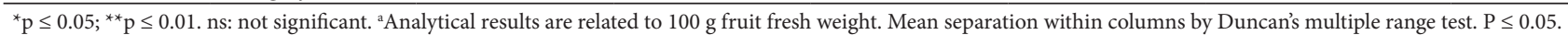

The antioxidant activity of the experimental factors is presented in Table 3. Non-significant differences in the antioxidant activity of cv. 'Anthem' were found in the LGS, but the antioxidant activity was significantly affected by the rootstock-scion combinations in the EGS $(p \leq 0.01)$. 'Anthem'/'Shintoza' recorded the highest antioxidant activity with $\mu \mathrm{mol} \mathrm{TE} / \mathrm{g} \mathrm{FW}$; rootstock-scion combinations analyzed declined in the following order: 'Anthem'/'Shintoza' > 'Anthem'/'Macis' > Self-grafted 'Anthem' > 'Anthem'/'Obez' > Self-rooted 'Anthem'. Significant differences were found in the antioxidant activity values of cv. 'Crimstar' in both the EGS and the LGS (both $p \leq 0.05$ ). The highest antioxidant activity was obtained from self-grafted 'Crimstar' in EGS and from self-rooted 'Crimstar' in the LGS. It was also seen that EGS increased the antioxidant activity in comparison to LGS for only cv. 'Anthem' by an average of $28.6 \%$. Antioxidants protect humans against free radicals, which can damage cells and increase the risk of developing cancer, cardiovascular diseases, and other degenerative disorders (Kaur \& Kapoor, 2001). The results are similar to the findings of Chávez-Mendoza et al. (2013), who reported differences in the antioxidant activity in relation to variety-graft interaction. 


\section{Conclusions}

Different ecologies and scion/rootstock combinations can result in variable fruit quality parameters in watermelon production across different environments. We found that there may also be variability and inconsistency in the fruit quality parameters of watermelons with different scion/rootstock combinations grown in two subsequent growing cycles in the summer season. A rule for changes in the fruit quality depending on the cultivar, rootstock, and/or growing season could not be assessed from the results of our experiments. Neither the vigorous hybrids of C. maxima $\times$ C. moschata (represented by 'Shintoza' and 'Obez') nor Lagenaria siceraria represented by 'Macis' could be categorized as having constantly superior fruit quality traits for at least one of the cultivars in at least one of the field trials.

Our results thus support the notion that fruit quality in watermelon does not represent a general phenomenon, rather it depends on the specific rootstock-scion interactions and the growth environment. This observation also highlights the need for selecting suitable scion/rootstocks for each growth condition created by ecology or growing cycle to guarantee high fruit quality. The LGS should be considered more seriously as it seems more sensitive toward creating a better environment for the expression of different quality traits as compared to the EGS. Also, it has been reported that the LGS creates a better environment for plant growth traits (main stem length, number of lateral vine, shoot dry weight etc.). An explanation of this could that the LGS starts directly in the open fields by the end June to the beginning of July and continues until autumn. Plants may not be exposed to low air and soil temperatures during the LGS which temperature is more suitable for watermelon cropping. The experiments need to be repeated by including histological studies on the affinity of the grafted tissue to further elucidate the inconsistency in the fruit quality parameters.

\section{Acknowledgements}

This research was supported by Ege University Science and Technology Center, Izmir, Turkey (grant number: 2012/OMYO/002).

\section{References}

Alan, Ö., Duzyaman, E., \& Sen, F. (2017). How growing cycles affect plant growth and yield of grafted watermelon combinations. Fresenius Environmental Bulletin, 26(6), 4214-4221.

Alan, Ö., Özdemir, N., \& Günen, Y. (2007). Effect of grafting on watermelon plant growth, yield and quality. Journal of Agronomy, 6(2), 362-365. http://dx.doi.org/10.3923/ja.2007.362.365.

Alexopoulos, A. A., Kondylis, A., \& Passam, H. C. (2007). Fruit yield and quality of watermelon in relation to grafting. Journal of Food Agriculture and Environment, 5, 178-179.

Aloni, B., Cohen, R., Karni, L., Aktas, H., \& Edelstein, M. (2010). Hormonal signaling in rootstock-scion interactions. Scientia Horticulturae, 127(2), 110-126. http://dx.doi.org/10.1016/j.scienta.2010.09.003.

Benincasa, P., Massoli, A., Polegri, L., Concezzi, L., Onofri, A., \& Tei, F. (2014). Optimising the use of plastic protective covers in field grown melon on a farm scale. Italian Journal of Agronomy, 9(1), 8-14. http://dx.doi.org/10.4081/ija.2014.556.
Benzie, I. F. F., \& Strain, J. J. (1996). The ferric reducing ability of plasma (FRAP) as a measure of "Antioxidant Power": the FRAP Assay. Analytical Biochemistry, 239(1), 70-76. PMid:8660627. http:// dx.doi.org/10.1006/abio.1996.0292.

Bletsos, F., \& Passam, H. C. (2010). Grafting: an environmentally friendly technique to overcome soil-borne diseases and improve the out of season production watermelon, cucumber and melon. In A. N. Sampson (Ed.), Horticulture in the 21st Century (pp. 81-120). New York: Nova Science.

Candır, E., Yetişir, H., Karaca, F., \& Üstün, D. (2013). Phytochemical characteristics of grafted watermelon on different bottle gourds (Lagenariasiceraria) collected from the Mediterranean region of Turkey. Turkish Journal of Agriculture and Forestry, 37, 443-456.

Chávez-Mendoza, C., Sánchez, E., Carvajal-Millán, E., Muñoz-Márquez, E., \& Guevara-Aguilar, A. (2013). Characterization of the nutraceutical quality and antioxidant activity in bell pepper in response to grafting. Molecules (Basel, Switzerland), 18(12), 15689-15703. PMid:24352022. http://dx.doi.org/10.3390/molecules181215689.

Chinnici, F., Spinabelli, U., Riponi, C., \& Amati, A. (2005). Optimization of the determination of organic acids and sugars in fruit juices by ionexclusion liquid chromatography. Journal of Food Composition and Analysis, 18(2-3), 121-130. http://dx.doi.org/10.1016/j.jfca.2004.01.005.

Colla, G., Rouphael, Y., Cardarelli, M., \& Rea, E. (2006). Effect of salinity on yield, fruit quality, leaf gas exchange, and mineral composition of grafted watermelon plants. HortScience, 41, 622-627.

Dadashpour, A. (2012). Impacts of different salt source and concentrations on germination and seedling growth of many pumpkin seeds used as rootstock in Iran. Genetika, 44(2), 235-250. http://dx.doi. org/10.2298/GENSR1202235D.

Davis, A. R., \& Perkins-Veazie, P. (2005). Rootstock effects on plant vigor and watermelon fruit quality. Report - Cucurbit Genetics Cooperative, 28-29, 39-42.

Davis, A. R., Penelope, P. V., Hassell, A., King, S. R., \& Zhang, X. (2008a). Grafting effects on vegetable quality. HortScience, 43, 1670-1672.

Davis, A. R., Perkins-Veazie, P., Sakata, Y., López-Galarza, S., Maroto, J. V., Lee, S. G., Huh, Y. C., Sun, Z., Miguel, A., King, S., Cohen, R., \& Lee, J. M. (2008b). Cucurbit Grafting. Critical Reviews in Plant Sciences, 27(1), 50-74. http://dx.doi.org/10.1080/07352680802053940.

Doolan, D. W., Leonardi, C., \& Baudoin, W. O. (1999). Vegetable seedling production manual. In: Food and Agriculture Organization, FAO Plant Production and Protection Paper (No. 155, pp. 1-81) Rome: FAO.

Edelstein, M., Tyutyunik, J., Fallik, E., Meir, A., Tadmor, Y., \& Cohen, R. (2014). Horticultural evaluation of exotic watermelon germplasm as potential rootstocks. Scientia Horticulturae, 165, 196-202. http:// dx.doi.org/10.1016/j.scienta.2013.11.010.

Evrenosoğlu, Y., Alan, Ö., \& Özdemir, N. (2010). Leaf phenolic content of some squash rootstocks used on watermelon (Citrulluslanatus (thunb.) Matsum and Nakai) growing and phenolic accumulation on grafted cultivar. African Journal of Agricultural Research, 5(8), 732-737.

Fallik, E., \& Ilic, Z. (2014). Grafted vegetables - the influence of rootstock and scion on postharvest quality. Folia Horticulturae, 26(2), 79-90. http://dx.doi.org/10.2478/fhort-2014-0008.

Hamid, A. A., Aiyelaagbe, O. O., Usman, L. A., Ameen, O. M., \& Lawal, A. (2010). Antioxidants: Its medicinal and pharmacological applications. AJPAC, 4, 142-151.

Huitrón-Ramírez, M. V., Ricardez-Salinas, M., \& Camacho-Ferre, F. (2009). Influence of grafted watermelon plant density on yield and quality in soil infested with melon necrotic spot virus. HortScience, 44, 1838-1841. 
Ibarra, L., Flores, J., \& Díaz-Pérez, J. C. (2001). Growth and yield of muskmelon in response to plastic mulch and row covers. Scientia Horticulturae, 87(1-2), 139-145. http://dx.doi.org/10.1016/S03044238(00)00172-2.

Karaca, F., Yetişir, H., Solmaz, İ., Çandır, E., Kurt, Ş., Sarı, N., \& Güler, Z. (2012). Rootstock potential of Turkish Lagenariasiceraria germplasm for watermelon: plant growth, yield and quality. Turkish Journal of Agriculture and Forestry, 36, 167-177.

Kaur, C. H., \& Kapoor, H. C. (2001). Antioxidants in fruits and vegetables the millennium's health. International Journal of Food Science \& Technology, 36(7), 703-725. http://dx.doi.org/10.1046/j.13652621.2001.00513.x.

King, S. R., Davis, A. R., Zhang, X., \& Crosby, K. (2010). Genetics, breeding and selection of rootstocks for Solanaceae and Cucurbitaceae. Scientia Horticulturae, 127(2), 106-111. http://dx.doi.org/10.1016/j. scienta.2010.08.001.

Kyriacou, M. C., Rouphael, Y., Colla, G., Zrenner, R., \& Schwarz, D. (2017). Vegetable grafting: The implications of a growing agronomic imperative for vegetable fruit quality and nutritive value. Frontiers in Plant Science, 8, 741. PMid:28553298. http://dx.doi.org/10.3389/ fpls.2017.00741.

Lee, J. M., Kubota, C., Tsao, S. J., Bie, Z., Echevarria, P. H., Morra, L., \& Oda, M. (2010). Current status of vegetable grafting: diffusion, grafting techniques, automation. Scientia Horticulturae, 127(2), 93-105. http://dx.doi.org/10.1016/j.scienta.2010.08.003.

Liu, H. Y., Zhu, Z. I., Qian, Q. Q., \& Ge, Z. P. (2004). The effects of different rootstocks on the sugar metabolism and related enzyme activities in small and early-maturing watermelon during fruit development. Acta Horticulturae, (31), 47-52.

Martinez-Ballesta, C. M., Alcaraz-Lopez, C., Muries, B., Mota-Cadenas, C., \& Carvajal, M. (2010). Physiological aspects of rootstock-scion interactions. Scientia Horticulturae, 127(2), 112-118. http://dx.doi. org/10.1016/j.scienta.2010.08.002.

McGuire, R. G. (1992). Reporting of objective color measurements. Hort Science, 27, 1254-1255.

Miguel, A., Maroto, J. V., San Bautista, A., Baixauli, C., Cebolla, V., Pascual, B., Lopez, S., \& Guardiola, J. L. (2004). The grafting of triploid watermelon is an advantageous alternative to soil fumigation by methyl bromide for control of Fusarium wilt. Scientia Horticulturae, 103(1), 9-17. http://dx.doi.org/10.1016/j.scienta.2004.04.007.
Mohamed, F. H., El-Hamed, K. E. A., Elwan, M. W. M., \& Hussien, M. N. E. (2014). Evaluation of different grafting methods and rootstocks in watermelon grown in Egypt. Scientia Horticulturae, 168, 145-150. http://dx.doi.org/10.1016/j.scienta.2014.01.029.

Proietti, S., Rouphael, Y., Colla, G., Cardarelli, M., De Agazio, M., Zacchini, M., Rea, E., Moscatello, S., \& Battistelli, A. (2008). Fruit quality of mini-watermelon as affected by grafting and irrigation regimes. Journal of the Science of Food and Agriculture, 88(6), 11071114. http://dx.doi.org/10.1002/jsfa.3207.

Rouphael, Y., Schwarz, D., Krumbein, A., \& Colla, G. (2010). Impact of grafting on product quality of fruit vegetables. Scientia Horticulturae, 127(2), 172-179. http://dx.doi.org/10.1016/j.scienta.2010.09.001.

Salam, M. A., Masum, A. S. M. H., Chowdhury, S. S., Monoranjan, D., Saddeque, M. A., \& Islam, M. R. (2002). Growth and yield of watermelon as influenced by grafting. Online Journal of Biological Sciences, 2(5), 298-299. http://dx.doi.org/10.3923/jbs.2002.298.299.

Schwarz, D., Öztekin, G. B., Tüzel, Y., Brückner, B., \& Krumbein, A. (2013). Rootstocks can enhance tomato growth and quality characteristics at low potassium supply. Scientia Horticulturae, 149, 70-79. http://dx.doi.org/10.1016/j.scienta.2012.06.013.

Soteriou, G. A., Kyriacou, M. C., Siomos, A. S., \& Gerasopoulos, D. (2014). Evolution of watermelon fruit physicochemical and phytochemical composition during ripening as affected by grafting. Food Chemistry, 165, 282-289. PMid:25038677. http://dx.doi. org/10.1016/j.foodchem.2014.04.120.

Swain, T., \& Hillis, W. E. (1959). The phenolic constituents of Prunusdomestica. I.: the quantitative analysis of phenolic constituents. Journal of the Science of Food and Agriculture, 10(1), 63-68. http:// dx.doi.org/10.1002/jsfa.2740100110.

Thaipong, K., Boonprakob, V., Crosby, K., Cisneros-Zevallos, L., \& Byrne, D. H. (2006). Comparison of ABTS, DPPH, FRAP, and ORAC assays for estimating antioxidant activity from guava fruit extracts. Journal of Food Composition and Analysis, 19(6-7), 669-675. http:// dx.doi.org/10.1016/j.jfca.2006.01.003.

Turhan, A., Özmen, N., Kuşçu, H., Serbeci, M. S., \& Seniz, V. (2012). Influence of rootstocks on yield and fruit characteristics and quality of watermelon. Horticulture, Environment and Biotechnology, 53(4), 336-341. http://dx.doi.org/10.1007/s13580-012-0034-2.

Yetişir, H., Sarı, N., \& Yücel, S. (2003). Rootstock resistance to Fusarium wilt and effect on watermelon fruit yield and quality. Phytoparasitica, 31(2), 163-169. http://dx.doi.org/10.1007/BF02980786. 